\title{
THE EFFECT OF MANDATORY IFRS ADOPTION ON EARNING MANAGEMENT AND POLITICAL CONNECTION AS MODERATION VARIABLES IN COMPANIES LISTED IN INDONESIA STOCK EXCHANGE
}

\author{
Wardhana Yogi Aris Vara Wisnu \\ Department of Accounting, Faculty Economics and Business, University of Airlangga, \\ Surabaya, Indonesia \\ E-mail: yogiaris90@gmail.com
}

\begin{abstract}
This study aims to look at the effect of IFRS mandatory adoption role on earnings management and to see the effect of political connections in influencing IFRS adoption of earnings management. The data used in this study came from companies listed on Indonesia Stock Exchange in 2010-2015. This research uses a quantitative approach, using moderation regression and independent t-test to answer the research hypothesis. Discretionary accruals are used as earnings management proxies. To test the influence of political connections in strengthening IFRS adoption of earnings management, moderation regression was used as the model. The independent t-test results showed that there are insignificant differences in earning management after three years mandatory IFRS adoption in Indonesia. The first regression equation result shows that adoption of IFRS in companies listed on the IDX had a insignificant effect on earnings management. The results of the second regression equation show that political connections have a significant influence on management earnings. The third regression equation shows that political connection moderation variables significantly influenced IFRS adoption of earnings management.
\end{abstract}

\section{KEY WORDS}

Adoption of IFRS, mandatory adoption, earning management, political connections, moderation variable, moderation regression.

The impact of globalization Era which increases affects the investment market in Indonesia from year to year. There are rapid growths of foreign companies investing in Indonesia, many MNC (Multi National Corporate) companies that open branches in Indonesia. There are difficulties arise due to differences in financial reporting standards used by foreign investors in Indonesia and in the country of origin of investors, which lead it to difficult situation for both parties involved in doing business in Indonesia.

The Comparability of a standard can be a comparable measure which is necessary, because it will have an impact on the effectiveness of a capital market activity, in this case if the standards apply internationally, the comparison of the company's financial performance can be compared, and international capital markets become more effective (Janjean, 2008).

The use of global standards is not a condition that can create a common business language, there are still several other important factors such as management incentives and related institutional factors that have an important role in forming financial reporting characteristics (Jeanjean \& Stolowy 2008).In his research, Ball et al (2003) also stated that High quality standards might be the conditions needed to form high quality information, but this is not always be true.

IFRS refers more to the principle base, professional judgment, and more disclosure is required, IASB said that IFRS can improve the quality of financial statements (source: TOT FEB UGM Material). In its own practice there is research that states that adoption of IFRS is not as expected as in China, after harmonizing Chinese GAAP with IFRS the timeliness of reported earnings reports in China is getting worse than before harmonization, this happened because the future expected earnings which increased after the effective implementation of IFRS in 2009 in China (Wu, Li, \& Lin, 2014).

The implementation of IFRS in several countries in Europe is different based on the 
accounting system in each country, even though IFRS is applied in order to get comparable reports, the output results remain different because there are different cultures and environments in each country in Europe (Callao, Ferrer \& Lainez, 2009).

Research conducted by Tendeloo \& Vanstraelen (2005) in Germany states that there is no change in earnings management between companies using German GAAP and companies that adopt IFRS voluntary, this is because the code-law country base where investor protection rights is still very low gives less reliable results.

Research related to IFRS adoption and earnings management occurs in various countries in the world such as in the Asian continent such as China, Malaysia and those in regions in various countries in continental Europe such as France, Americas such as Brazil. Europe is one of the continents where countries on the continent show a fundamental difference in results, that the results of IFRS are not necessarily the same in each country. These differences depend on the legal structure (common law or code law), accounting culture, politics, institutions and many other factors and this is supported by the statement of Ball et al. (2003) that high quality standards are a necessary condition to obtain high quality information, but this is not always true.

Facio (2010) explained in his research that companies are considered to have political connections if at least one of the major shareholders or one of the company's leaders, CEO, vice president and secretary are members of parliament, ministers or people related to politics or commonly referred to as Politically exposed person (PEP). Political connections also play an important role in explaining the variance in the selection of a company's earnings management strategy (Braam, Nandy, \& Lodh, 2015, p. 26).

The use of politics in the accounting world is introduced through the political cost hypothesis in positive accounting theory (PAT), which states that high profitability can attract the attention of mass media and consumers, which in turn can trigger political heat. Political heat triggers the emergence of new regulations aimed at companies that have high profitability (Scott 2005). Corporate Social Responsibility (CSR) is an example of regulation that arises from the impact of company profitability, because profitable companies are considered to have social and environmental responsibilities in which the company is located.

All accrual accounting includes opinions regarding future cash flow which results in a lot of freedom in implementing accounting rules. Economists and local politicians who have power or influence can determine how managers, auditors, court regulations and other parties influence the implementation of regulations (Ball, 2006).

The idea to test political connections as a moderating variable refers to the statement of Baron \& Kenny, (1986) which states that moderators and predictors are at the same level in their roles as causal variables, antecedent variables, or exogenous variables and moderating variables also always function as independent variables. Judging from the results of previous research Braam et al., (2015) and Harymawan et al., (2016) which state political connections have the effect of earnings management.

Based on the Positive Accounting Theory proposed by Watts and Zimmerman (1990), the selection of policies carried out by management is based on bonuses, debt contracts and political costs which are the motivations of management in earning management.

\section{LITERATURE REVIEW}

IASB or International Financial Standards Board (IASB) established in London in 1973 which was originally called IASC (International accounting standard committee) Natawidyana (2008) states that most of the standards that were part of IFRS were from International Accounting Standards (IAS).

IFRS convergence in Indonesia is carried out in three ways, first through adoption, namely direct IFRS (standardization), adaptation, namely making its own standards that do not conflict with IFRS, and harmonization that is synergizing standards with international accounting standards or not fully complying with international standards.

Based on IAI (Ikatan Akuntan Indonesia) that, the full convergence of PSAK towards 
IFRS will be carried out in three stages, namely the stages of IFRS adoption (2008-2010), the final preparation stage in 2011, and the implementation stage of IFRS (2012) by gradually implementing PSAK based on IFRS and comprehensive application of PSAK (www.iaiglobal.or.id).

The Positive Accounting Theory is all things related to predicting situations, such as management's response in choosing policies and implementing new accounting standards (Scott p-304, 2005).Positive Accounting Theory or PAT has Three Hypotheses (Watts and Zimmerman, 1990):

The Bonus Plan Hypothesis - in the bonus plan hypothesis, management chooses accounting procedures that shift the existing profit in the future to be put at the moment. For example, management bonus increases with increasing net income, so that management gets a high bonus, management increases their bonus by increasing net income one of the efforts made by choosing accounting policies that increase current earnings reports which ultimately reduce profits existing in the future period.

The debt Hypothesis - in the corporate debt contract hypothesis that pays for accounting based on debt contracts has a tendency to choose accounting procedures that shift earnings in the current period. Future earnings shift to the current period will increase net income and will reduce the likelihood that the compliance will meet the loan obligations, because in a borrower's debt contract must meet the conditions of the agreement.

The Political Cost Hypothesis - in the political cost hypothesis, the more likely the political costs faced by the company this period, the manager will choose an accounting procedure that postpones / suspends the current period's earnings to the future period. Political costs arise due to the high profitability of the company (Scott 2005), for example high profitability can lead to the emergence of new regulations such as taxes etc, and companies that have high profitability are large companies that will be faced with high performance standards and responsibility for the environment around the company increase.

The company is said to have a political connection if at least one of the large shareholders (someone who directly or indirectly controls at least $10 \%$ of the total voting shares) or one of the leaders of the company (CEO, President Director, Vice President Director, or secretary) is a member of parliament or a minister or head of state or very closely related to the company.

Accrual methods are conceptually accruals whose values are determined by management (discretion) policies. Technically, accrual itself is the differences between profit and cash. Detection of the possibility of earnings management in financial statements is generally investigated through the use of accruals, because accruals themselves are the main components of profit making and their arrangement is based on certain estimates determined by management.

Accrual accounting attempts to record the financial impact on an entity of transactions and other events related to the consequences of cash for the entity in the period in which the related transactions and events arise rather than only in the period where cash is received and paid by the entity (FASB 1985, SFAC No. 6 Paragraph 139).

Nondiscretionary Accrual - Normal accrual or non-discretionary accrual is part of the accrual that is naturally available in the process of preparing financial statements. Nondiscretionary accrual is a component of accrual that occurs along with changes in company activities (Jones, 1991).

Discretionary Accrual - Discretionary accrual is an accrual component derived from earning management by a manager. Discretionary accruals are equivalent to abnormal accruals or commonly referred to as unexpected accruals. Discretionary accrual is an option to choose the policy given to the manager.

Earning management is the selection of accounting policies or concrete actions that affect earnings by management, to achieve specific goals in earnings reporting (Scott, 2009). Earning Management arises when managers use valuation in financial reporting and in the formation of transactions to change financial reporting to mislead stakeholders regarding the performance of the company concerned or for contractual results that depend on the amount of accounting reported (Healy \& Wahlen, 1999). 
Modified Jones model derived from Jones model (Jones, 1991) is used to determine discretionary accruals, Modified Jones is a modification of the Jones model by adding changes in revenue as a deduction of changes in receivable.

\section{HYPOTHESIS DEVELOPMENT}

Until now, more than 100 countries have adopted IFRS as an accounting standard and applied in companies in their country, even though there are used it voluntary or mandatory. IFRS is claimed by the IASB to improve the quality of financial statements, but in practice the use of IFRS in various countries has produced different results even though they are adopted IFRS. Previously several studies have been conducted to see the difference after adopting IFRS on earnings management. In his research, Capkun (2016) conducted research in 29 countries from 1994 to 2004 and the results showed no difference in earnings management before and after the adoption of IFRS. Different results are shown by research conducted by Lei Cai (2008). The study was conducted in 32 countries between 2000-2006 which stated that there were differences in earning management in countries adopting IFRS.

The difference in the results of IFRS adoption in various countries was explained by Barth in his research that the implementation of high quality standards such as IFRS also depends on political, legal and accounting systems to get the full benefits of IFRS adoption. Indonesia enforces mandatory IFRS adoption to be effective on 1 January 2012 but adoption of IFRS in Indonesia itself has been carried out in stages since 2008. After mandatory adoption of IFRS in 2012 is there a difference in earnings management after IFRS adoption took effect in 2012 for companies that which is listed on the Indonesia Stock Exchange. Based on the results of previous studies, the hypothesis can be made as follows:

$\mathrm{H} 1$ : Earning management has changes after three years mandatory IFRS adoption enforces in 2012 for companies listed on the IDX (Indonesia Stock Exchange).

Earning management practices can work because of the freedom of policy selection made by management in making financial reports, but that freedom still refers to the applicable standards, because IFRS is a high quality standard it is considered able to improve the quality of financial statements.

Within a few years it was known that there was an increase in the quality of earnings which meant that earnings management practices had been reduced after several years of IFRS adoption in Malaysia (Adibah et al., 2013) and (Sellami et al., 2013), but this was different from the results of the study conducted by (Wu et al., 2014) in China after adopting IFRS the timeliness of earnings reporting worsened over time, this shows that the IFRS advertisement actually decreases the quality of earnings before the PRC GAAP period in China.

There are differences in results in some countries that adopt IFRS, there are countries that do experience an increase in the quality of earnings but there are also in some other countries that have not increased (Capkun et al., 2016) and (Daske et al., 2008). that the effect of IFRS Adoption on earnings management will be different from each country and the adoption period is carried out. Based on the results of previous studies, the hypothesis can be made as follows:

H2: Adoption of IFRS has an effect on earnings management.

Theoretical research on political connections shows that companies benefit from their connections because they can better understand the public policy process, gain direct access to politicians, bureaucracies, and decision makers who influence political decisions (Hillman, 2005).

In his research, Chaney et al. (2011) stated that the quality of earnings of companies that have political connections is worse than companies that do not have political connections. This happens because companies that have political connections do not respond too much to the pressure from the capital market to improve their earnings information quality and they also do not risk punishment because they show less quality accounting information to the public.

In his research Braam et al., (2015) stated that political connections can influence 
earnings management practices more than the earnings management strategies used. The choice of strategy is more to when using accrual and real earnings management. In the research conducted by Harymawan \& Nowland, (2016), it shows that the quality of earnings in companies that have a political relationship increases with increasing government effectiveness and will tend to decline when the political environment is stable. So it can be said that political connections have an influence on earnings management. Based on the results of previous studies, the hypothesis can be made as follows:

H3: Political connection influences earnings management.

In his research Soderstrom \& Sun, (2007) states that the system of legality and politics affect accounting quality indirectly through accounting standards, which is explained that the preparation of accounting standards is a political process. In its efforts to reduce political influence, users of financial statements such as those authorized by tax, representatives of banks, share holders are also involved in the process. The political system can also directly affect the quality of accounting in countries that have a corrupt political system. Management can bribe politicians to request government purchases, lower tax payments, and monopoly status.

In a company in the ranks of top management the selection of policies regarding accounting standards is determined by the Board of Directors and the Board of Commissioners. Let's say that in one company, one of them is BOD and BOC has a political connection, so they have more access to regulators as suggested by Hillman et al (2005) in their research. This is of course a distinct advantage for companies that have political connections compared to companies that have no political connections.

One of the advantages of companies that have political connections is explained in his research Chaney et al (2011) that the company does not have the risk of penalties if it shows a lack of quality accounting reports., so it can be said that even though the adoption of high quality standards such as IFRS cannot be fully optimized because of the political connections that BODs and BOCs have because political connections can also intervene indirectly in the standard adoption process. If viewed from the results of the previous research had described above, it can be concluded that if IFRS adoption interacts with political connections it can be said that it can reduce the benefits of IFRS adoption in its objectives that improve the quality of financial statements. And in this case the context of the quality of financial statements is seen from earning management carried out by the company. Based on the results of the above research, the following hypotheses can be made:

H4: Political connection moderating IFRS adoption of earnings management.

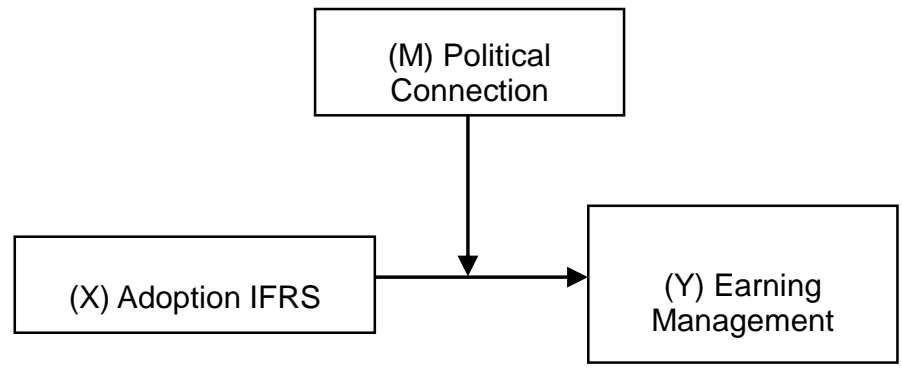

Figure 1 - Research Model

Regression Equation Model from the research model above:

$E M=$ AdoptionIFRS $+F S I Z E+L E V+G R O W T H+Y E A R+I N D U S T R I \ldots(1)$

$E M=$ AdoptionIFRS + PoliticalConection + FSIZE $+L E V+G R O W T H+Y E A R+I N D U S T R I . .(2)$

EM=AdoptionIFRS + PoliticalConection $+($ AdoptionIFRSxPoliticalConection $)+F S I Z E+L E V$ + GROWTH +YEAR+INDUSTRI ....(3) 


\section{METHOD OF RESEARCH}

The type of research used in this study is quantitative research. Quantitative research focuses more on theories through testing variables with statistical procedures (Sekaran, 2006). The type of data in this study is secondary data because the data are financial reports from the Indonesia Stock Exchange to measure IFRS adoption, discretionary accruals, firm size, leverage, growth and summary financial statements to determine SIC (Sector Industry Code) and the type of measure used is nominal data source from the research in the form of audited financial statements obtained from the IDX website (www.idx.org). The research sample is all companies listed on the IDX (Indonesia Stock Exchange) except all financial sector companies such as the bank sub-sector, financial institutions, securities companies. The population in this study must meet several criteria to avoid incomplete data or misspecification. Criteria used include:

- There are no financial statement data lost during the study period;

- Companies that publish financial reports and annual reports in 2010-2015;

- There are no data from companies engaged in financial, bank sub-sector, securities companies (SIC 8);

- There are no BUMN company in list (State-Owned Enterprise);

- There are no new company was listed on the IDX in 2014 and 2015.

The independent variable in this study is IFRS adoption. The variables of IFRS adoption are measured as in the research of Wan Ismail et al., (2013) and Rudra \& Bhattacharjee (2012) which are dummy variables consisting of values 0 and 1 , worth 1 in financial statements after 2012, mandatory IFRS is applied and has a value 0 before 2012 .

The dependent variable in this study is earnings management. Earning management variables were measured as in Dechow's research (1995) using discretionary accrual as earnings management proxy and using modified Jones models as discretionary accrual measurement models. Modified Jones models are the best testing model for measuring earnings management compared to Healy De Angelo, standard Jones models and industry models (Dechow et al 1995):

$$
\begin{gathered}
T A_{t}=\text { NetIncome }-C F O / \operatorname{ASSET}_{t-1} \ldots . .(4) \\
N D A_{i t}=\alpha_{1}\left(1 / A S S E T_{t-1}\right)+\alpha_{2}\left(\Delta R E V_{i t}-\Delta R E C_{i t} / \operatorname{ASSET}_{t-1}\right)+\alpha_{3}\left(P P E_{i t} / A S S E T_{t-1}\right)+e_{i t} \ldots(5) \\
D A_{i t}=T A_{i t}-N D A_{i t} \ldots .(6)
\end{gathered}
$$

Where: $T A_{i t}=$ Company Total accrual $\mathrm{i}$ in year $\mathrm{t}$; $A S S E T_{t-1}=$ Total Asset in year $\mathrm{t}-1$; $\triangle R E V_{i t}=$ Changes of sales company $\mathrm{i}$ in year $\mathrm{t} ; \triangle R E C_{i t}=$ change of receivable company $\mathrm{i}$ in year $\mathrm{t} ; P P E_{i t}=$ Property Plant and Equipment company $\mathrm{i}$ in year $\mathrm{t} ; \alpha_{1}, \alpha_{2}, \alpha_{3}=$ firm-specific parameters ; $\triangle C F O=$ Cash Flow from Operation activities.

The moderating variable in this study is political connection. In research, measuring political connections is measured as in a study conducted by Harimawan et al (2017) using a politically exposed person (PEP). Exposed person politic is categorized as president, minister or equal position, governor, director of BUMN, head and political party, senior TNI or Police, senior judiciary, and relations with parties who have political connections with one line (parents, siblings, child). Value 1 if one of the BOD and BOC has one of the points above and vice versa is worth 0 if it does not have the above category.

Measured firm size as in the study of Daniel Zeghal (2011) by using natural logarithms from the total value of the company's assets:

$$
\text { FSIZE }=\text { In (Company Total Assets) }
$$


Leverage is measured as in the Capkun (2016) study using a ratio by means of total liabilities (current and long-term) divided by the total assets of the company:

$$
\mathrm{DER}=\text { total liabilities } / \text { total equity }
$$

Growth is measured as in Capkun research (2016) using the percentage change in sales by means of sales minus the previous year's sales, and divided by previous year's sales:

$$
\text { Sales GROWTH= } \text { Sales }^{-} \text {Sales }_{t-1} \text { SSales }_{t-1}
$$

Year is Year Fixed Effect is a fixed effect model in the formulation of regression. The existing intercept panel data varies for each subject, but the slope of each sub-object remains. So to distinguish one subject from another subject, dummy variables are used.

Industry is Industry fixed effect is a fixed effect model in the formulation of regression similar to the year fixed effect. The existing intercept panel data varies for each subject, but the slope of each subject remains. So to distinguish another subject, a dummy variable is used.

\section{RESULTS AND DISCUSSION}

Descriptive statistics provide a general description of the variables tested in the study. Descriptive statistics provide information about the minimum, maximum, average and standard deviations of these variables. This descriptive statistic comes from 1652 observations over a period of 6 years.

Table 1 - Variable Description

\begin{tabular}{llllll}
\hline Variable & $\mathrm{N}$ & Mean & Std. Dev & Min & Max \\
\hline A_IFRS & 1652 & 0.6658596 & 0.4718319 & 0 & 1 \\
KP & 1652 & 0.2748184 & 0.4465579 & 0 & 1 \\
ABS_DA & 1652 & 0.7705677 & 4.63825 & 0.0000253 & 76.04256 \\
FSIZE & 1652 & 17.60919 & 3.256142 & 6.512473 & 29.70149 \\
LEVERAGE & 1652 & 2170141 & 84411.38 & -51.33274 & 3427959 \\
GROWTH & 1652 & 0.3042138 & 5.432928 & -1.000 & 215.1378 \\
\hline
\end{tabular}

Source: Data Processed with Stata 14.

Note: $A$ IFRS is IFRS adoption, the value will be 1 if it has been adopted IFRS and has 0 vice versa; KP is a political connection referring to a PEP or political exposed person; ABS_DA is the absolute value of discretionary accrual that refers to the modified Jones model; FSIZE is the size of the company referring to the value of the natural logarithm of company total assets; LEVERAGE refers to DER; GROWTH refer to sales Growth.

In table 1 is the result of the descriptive statistics of the research variables from the 2010-2015 year. There is 1652 Observation. Detail the results of descriptive statistics explained as follows:

- Variable A_IFRS Adoption of IFRS is a dummy variable that has an average value of 0.665 with a range of minimum and maximum values of 0 and 1 , and has a standard deviation value of 0.471 ;

- KP variable or political connection here is a dummy variable that has an average value of 0.274 and a standard deviation of 0.446 with a range of minimum and maximum values of 0 and 1 ;

- The average value of the ABS_DA variable or discretionary accrual is 0.7705 with minimum and maximum values of 0.000 and 76.0425 with a standard deviation value of 4.6382 ; 
- The average value of the firm size is 17.6091 and the minimum and maximum range values are 6.5124 and 29.7041 , and have a standard deviation of 3.2561 ;

- The average value of leverage is 2170 with a minimum and maximum range of -51 , 3327 and 3427 , and has a standard deviation of 8441 ;

- The average value of growth is 0.3042 with a minimum and maximum range of $-1,000$ and 215,1378 , and has a standard deviation of 5,4329.

Independent t-test is used to see the differences between two categories by comparing the mean values between variables. In this t-test the variables were categorized into two groups, namely the category of pre-mandatory IFRS Adoption and 2013-2015 postmandatory IFRS Adoption.

Table 2 - Independent t-test

\begin{tabular}{ccccc}
\hline Period & $\mathrm{N}$ & Mean & Std. Dev & P-value \\
\hline Earning management & & & & \multirow{2}{*}{0.1254} \\
Pre Mandatory IFRS & 551 & 0.5330 & 4.2707 & 4.8095 \\
Post Mandatory IFRS & 1101 & 0.8897 & & \\
\hline
\end{tabular}

Source: Data Processed with Stata 14.

The statistical test of independent t-test on earning management variables has a probability value of 0.1254 , this value is greater than $0.05(0.0116>0.05)$. These results indicate that $\mathrm{H} 1$ is rejected, meaning that there is no significant difference between earnings management before mandatory IFRS and after mandatory adoption of IFRS. Viewed from the mean (average) shows that after adoption, the mean is higher with a value of 0.8897 compared to before the mandatory adoption of IFRS with a value of 0.5330 . The results of the Independent t-test above did not support $\mathrm{H} 1$, namely earning management experienced a difference after three years after the entry into force of IFRS in mandatory in 2012 for companies listed on the IDX (Indonesia Stock Exchange).

Based on the results of the independent t-test hypothesis one which states that there are differences in earnings management after IFRS mandatory adoption is rejected, because based on the results of the independent t-test there is no difference after mandatory IFRS adoption in 2012. These results are indicated by $p$-value values greater than $5 \%(0.125$ $<0.05)$ and the t value is smaller than the t-table value $(-1.5337<1.960)$ which is significant at the $5 \%$ level. The results of this study which showed no difference in the level of earnings management after mandatory adoption of IFRS as well as research conducted by Christensen (2008) and Van Tendeloo \& Vanstraelen, (2005). This result is different from the previous research which states that there are differences in earnings management after adopting IFRS (Barth, Landsman, \& Lang, 2008; Pelucio-Grecco et al., 2014; Zéghal et al., 2011). These results do not match what said by the IASB (International Accounting Standard Board) that the use of IFRS can improve the quality of earnings.

Moderation regression analysis is used to assess empirically the relationship between IFRS adoption towards earnings management, political connections to earnings management and the moderating effect political connection variables in influencing the influence of FIRS adoption on earnings management in listed companies on the Indonesian stock exchange in 2010-2015.

Based on the results of the one equation regression one which tested there was an effect of IFRS adoption on earnings management, indicating that the second hypothesis refer to IFRS adoption affected earnings management was rejected. It can be seen that the $p$ value of IFRS adoption of earning management is smaller than $0.146(0.146>0.01)$ and the coefficient of -0.571 . This indicates that IFRS adoption has a negative and insignificant effect on earnings management, which means that adoption of IFRS has no effect in reducing earnings management practices in companies listed on the IDX.

The results of the regression equation above show that IFRS adoption has no effect on earnings management after mandatory IFRS adoption implemented, this result is similar to the results of previous studies stating that there is no decrease in earnings management 
after IFRS adoption (Christensen, 2008; Ahmed et al, 2010; Rudra et al., 2012). This result is different from the results of previous studies stating that IFRS adoption has an influence in reducing earnings management practices (Barth, Landsman, \& Lang, 2008; Pelucio-Grecco et al., 2014; Zéghal et al., 2011).

Table 2 - Regression Equation

\begin{tabular}{llll}
\hline & Equation 1 & Equation 2 & Equation 3 \\
Variable & ABS_DA & ABS_DA & ABS_DA \\
\hline A_IFRS & -0.572 & -0.572 & -0.628 \\
KP & -0.146 & -0.145 & -0.110 \\
& - & $-0.771^{* * *}$ & $-1.484^{* * *}$ \\
A_IFRSxKPs & - & $-0,002$ & 0 \\
& & - & $1.072^{* *}$ \\
FSIZE & $-0.297^{* * *}$ & $-0.308^{* * *}$ & $-0,038$ \\
& 0.000 & 0.000 & $-0.309^{* * *}$ \\
LEVERAGE & 0.000 & 0.000 & 0.000 \\
& $-0,945$ & 0.000 & 0.000 \\
GROWTH & -0.002 & 0,000 & 0.000 \\
Constant & -0.932 & -0.991 & 0,002 \\
Observation & $6.498^{* * *}$ & $6.809^{* * *}$ & -0.912 \\
R-squared & & & $7.066^{* * *}$ \\
Industry & 1652 & 1652 & \\
Year & 0.102 & 0.108 & 1652 \\
Adjusted R-squared & Included & Included & 0.11 \\
\hline
\end{tabular}

Source: Data Processed with Stata 14.

Note: ${ }^{* * *}, * *, *$ represent the statistical significance at the level respectively $1 \%, 5 \%, 10 \%$.

Result of Regression Equation 1:

ABS_DA $=-0,016328-0,213$ A_IFRS - 0,171 FSIZE - 0,140 LEV - 0,006 GROWTH

The results of research by Barth et al (2008) in 21 countries stating that Adoption of IFRS succeeded in reducing earning management and recognition of losses more timely, the number of share prices and associated income was higher.

The results of research by Zéghal et al. (2011) in France state that mandatory adoption of IFRS reduces the level of earnings management of companies that have good corporate governance and those who depend on foreign capital markets. In the results of the research by Pelucio-Grecco et al., (2014), the success of IFRS adoption in reducing earnings management due to regulatory support that regulates investor protection, without regulations that regulate the adoption of IFRS will be successful in reducing earnings management practices.

Positive Accounting Theory is all things related to predicting situations, such as management response in choosing policies and applying new accounting standards (Scott, 2005). In accrual accounting, the accrual method in concept is determined by management discretion and earnings management estimation is generally examined through the use of accruals because accruals themselves are the main component of earnings earning. It can 
be said that PAT and accrual accounting are interrelated because discretion or the selection of accounting policies can affect the value of earnings of the company. Adoption of IFRS affects earnings management not in theory because the management of IFRS-based policies by the management does not affect the company's earnings management. The results of this study differ may be influenced by other factors such as differences in legal and political systems (Ball, 2006).

Result of Regression Equation 2:

$$
A B S \_D A=-0,0014269-0,213 \text { A_IFRS - 0,098 KP - 0,177 FSIZE - 0,77 LEV - 0,004 GROWTH }
$$

The results of the equation regression two which examined the effect of political connections on earnings management showed that the third hypothesis, refer to political connections affecting earnings management, was accepted. Political connections have a significant negative effect on earnings management. can be seen from the value of $p$ value KP against ABS_DA 0.002 smaller than $0.01(0.002<0.01)$, and the coefficient worth -0.770 . this shows that political connections can reduce the level of earnings management.

The regression results of equation 2 shows that political connections can influence earnings management, these results are also obtained in previous studies (Faccio, 2010; Braam et al., 2015; Harymawan et al., (2016); Jin lao (2015). Bram (2015) said that political connections influence the selection of earnings management strategies used by companies. In his research, Harymawan et al (2006) stated that earnings management increases with government effectiveness, which means that regulations set by the government can affect earnings management. regression test equation 2 shows that the third hypothesis is accepted, because political connections affect earnings management significantly $(0.002$ $<0.01$ ) with a coefficient of -0.770 .

The results of this study are different from the results of the research by Imashan (2017). In a study conducted by Imanshan (2017) stating that there is no influence of political connections on earnings management, the results of this difference may be due to differences in political connection proxies used in imashan's research (2017) where political connections are proxied through the government's share ownership of the company. The political connection proxies are different from the proxies used in this study that use political exposed person (PEP) as a proxy for political connections.

When the Board of Directors and Board of Commissioners have positions in the government or are state apparatus, as well as members of political parties that have influence in regulating regulations. Then the BOD or BOC has the advantage of making regulations which impact on policies that must be stabilized by company management which can benefit them and weaken their business competitors. Profitable policies will certainly affect the company's earnings. The strength of the political connection that BOD and BOC has is in accordance with the bonus plan hypothesis in positive accounting theory, where if earnings increase, bonuses also increase. It can be said that the bonus obtained by management depends on the way the management manages profits, which makes political connections influence the earnings management strategy used. So the political connection affects the earnings management in accordance with the results of this study.

Result of Regression Equation 3:

$$
\begin{gathered}
A B S \_D A=0,2183-0,013 A \_I F R S \times K P-0,218 A \_I F R S-0,108 \mathrm{KP}-0,1769 \mathrm{FSIZE}-0,142 \text { LEV - } \\
0,003 \mathrm{GROWTH}
\end{gathered}
$$

Based on the results regression equations three were conducted to examine the effect of political connections in moderating the effect of IFRS adoption on earnings management, indicating that political connections weakened the effect of IFRS adoption on earnings management or moderated the effect of IFRS adoption on earnings management. Based on the results of the regression test equation three shows that the fourth hypothesis is accepted.

Based from the $p$ value A_IFRSxKP towards ABS_DA greater than $0.038(0.038<0.05)$ and the coefficient vaue 1.0721 , this indicates that the interaction variable A_IFRSXKP has a 
significant positive effect on earnings management so if there is a 1 point increase A_IFRSXKP then ABS_DA will increase only the coefficient value. because political connections increase the influence of IFRS adoption on earnings management. This may be because the political connection strategy contradicts the objectives of IFRS adoption itself, it can be said that political connections can influence earnings management strategies used by companies (Braam et al., 2015). Adoption of IFRS is considered to reduce the practice of earnings management which limits the earnings management strategy that can be done (Braam et al., 2015). It can be concluded that political connections can weaken the effect of IFRS adoption on earnings management even though it is the same as IFRS adoption which can negatively affect earning management which makes the fourth hypothesis accepted.

The results of this study are the same as Song et al., (2011) which also uses political connections as a moderating variable and where the results of research on political connections have been able to moderate IFRS adoption of earnings management. This result is the same even though there are differences in predictor variables used, in his study (Song et al., 2011) using EPS / Price which was interacted with political connections, his research results indicate that political connections moderate the influence of EPS / Price on earning management while using this study IFRS adoption as a predictor variable which is a dummy variable. The results of this study indicate that political connections moderate the effect of IFRS adoption on earnings management. The results of this study are the same as the results of the research conducted (Song et al., 2011a) although there are differences in the object of research in this study the object of research is all companies listed on the IDX, namely companies that are open or open to the public. al., (2011) the object of research is a private company.

In PAT theory above, it has been explained that IFRS adoption can influence earning management. The results of this research do not support the theory because the results of this study do not indicate the influence of IFRS adoption on earnings management. In contrast to political connections, the results of the study show that political connections can affect earnings management. When BOD and BOC companies have political connections they have the opportunity to regulate the regulations which make IFRS adjust to existing regulations and make the management of other companies follow standards that do not conflict with regulations and benefit BOC and BOD who have such political connections.

The results of the interaction between IFRS and political connections have an influence on earnings management. These results may be caused by differences in the objectives of each variable. IFRS adoption aims to reduce earnings management, while on political connections the effect on earning management is more on the selection of strategies used in earning management, which impacts on the higher earning management by the company if the company has political connections. So it can be said that political connections have a role that can weaken the effect of adopting IFRS on earnings management in accordance with PAT theory. When BOD and BOC companies have political connections they have the opportunity to regulate regulations which make IFRS adjust to existing regulations and make the management of other companies follow standards that do not conflict with regulations and benefit BOC and BOD who have such political connections.

The results of the interaction between IFRS and political connections have an influence on earnings management. These results may be caused by differences in the objectives of each variable. IFRS adoption aims to reduce earnings management, while on political connections the effect on earning management is more on the selection of strategies used in earning management, which impacts on the higher earning management by the company if the company has political connections. So it can be said that political connections have a role that can weaken the effect of adopting IFRS on earnings management in accordance with PAT theory.

\section{CONCLUSION}

Based on the results of the tests that have been obtained and as the discussion that has been explained in the previous chapter, it can be concluded several things as follows: there is no significant differences in earning management after three years mandatory IFRS 
adoption in company listed in IDX this shows that adoption of IFRS still has not shown results in reducing earnings management in IDX-listed companies. IFRS adoption has no effect on earnings management. Adoption of IFRS has no effect on earnings management indicating that adoption of IFRS cannot reduce earnings management practices. Political connections have a negative effect on earnings management. This shows that political connections are influential in reducing the practice of earnings management. The moderating variable weakens the effect of IFRS adoption on earnings management. This shows that companies that have political connections have a tendency to do earnings management for their own benefit that make adoption of IFRS no fully optimal.

\section{REFERENCES}

1. Adibah Wan Ismail, W., Anuar Kamarudin, K., Van Zijl, T., \& Dunstan, K. (2013). Earnings quality and the adoption of IFRS-based accounting standards: Evidence from an emerging market. Asian Review of Accounting, 21(1), 53-73.

2. Ball, R., Robin, A., \& Wu, J. S. (2003). Incentives versus standards: properties of accounting income in four East Asian countries. Journal of Accounting and Economics, 36(1), 235-270.

3. Barth, M. E., Landsman, W. R., \& Lang, M. H. (2008). International accounting standards and accounting quality. Journal of Accounting Research, 46(3), 467-498.

4. Braam, G., Nandy, M., Weitzel, U., \& Lodh, S. (2015). Accrual-based and real earnings management and political connections. The International Journal of Accounting, 50(2), 111-141. https://doi.org/10.1016/j.intacc.2013.10.009

5. C., Jarne, J. I., \& Lainez, J. A. (2009). The impact of IFRS on the European Union: Is it related to the accounting tradition of the countries? Journal of Applied Accounting Research, 10(1), 33-55.

6. Capkun, V., Collins, D., \& Jeanjean, T. (2016a). The effect of IAS/IFRS adoption on earnings management (smoothing): a closer look at competing explanations. Journal of Accounting and Public Policy, 35(4), 352-394.

7. Capkun, V., Collins, D., \& Jeanjean, T. (2016b). The effect of IAS/IFRS adoption on earnings management (smoothing): a closer look at competing explanations. Journal of Accounting and Public Policy, 35(4), 352-394.

8. Chaney, P. K., Faccio, M., \& Parsley, D. (2011). The quality of accounting information in politically connected firms. Journal of Accounting and Economics, 51(1-2), 58-76.

9. Daske, H., Hail, L., Leuz, C., \& Verdi, R. (2008). Mandatory IFRS reporting around the world: Early evidence on the economic consequences. Journal of Accounting Research, 46(5), 1085-1142.

10. Dechow, P. M., Sloan, R. G., \& Sweeney, A. P. (1995). Detecting earnings management. Accounting Review, 193-225.

11. Doukakis, L. C. (2014). The effect of mandatory IFRS adoption on real and accrual-based earnings management activities. Journal of Accounting and Public Policy, 33(6), 551572.

12. Harymawan, I., Harymawan, I., Nowland, J., \& Nowland, J. (2016). Political connections and earnings quality: How do connected firms respond to changes in political stability and government effectiveness? International Journal of Accounting \& Information Management, 24(4), 339-356.

13. Healy, P. M., \& Wahlen, J. M. (1999). A review of the earnings management literature and its implications for standard setting. Accounting Horizons, 13(4), 365-383.

14. Hillman, A. J. (2005). Politicians on the board of directors: Do connections affect the bottom line? Journal of Management, 31(3), 464-481.

15. Iatridis, G., \& Rouvolis, S. (2010). The post-adoption effects of the implementation of International Financial Reporting Standards in Greece. Journal of International Accounting, Auditing and Taxation, 19(1), 55-65.

16. Jeanjean, T., \& Stolowy, H. (2008). Do accounting standards matter? An exploratory analysis of earnings management before and after IFRS adoption. Journal of Accounting 
and Public Policy, 27(6), 480-494.

17. Jones, J. J. (1991). Earnings management during import relief investigations. Journal of Accounting Research, 193-228.

18. Latan, H. (2014). Aplikasi Analisis Data Statistik untuk IImu Sosial Sains dengan Stata. Bandung: Alfabeta.

19. Pelucio-Grecco, M. C., Geron, C. M. S., Grecco, G. B., \& Lima, J. P. C. (2014). The effect of IFRS on earnings management in Brazilian non-financial public companies. Emerging Markets Review, 21, 42-66.

20. Purwanto S.K, S. (2009). Statistika: Untuk Ekonomi dan Keuangan Modern. 2nd ed. Jakarta: Salemba Empat.

21. Sellami, M., \& Fakhfakh, H. (2013). Effect of the mandatory adoption of IFRS on real and accruals-based earnings management: Empirical evidence from France. International Journal of Accounting and Economics Studies, 2(1), 22-33.

22. Sekaran, U. (2011). Research Method For Bussines. 4th ed. Jakarta: Salemba Empat.

23. Soderstrom, N. S., \& Sun, K. J. (2007). IFRS adoption and accounting quality: a review. European Accounting Review, 16(4), 675-702.

24. Song, Y., Wang, L., \& Yan, Z. (2011). Impacts of Political Connections on Earnings Quality of Chinese Private Listed Companies (Vol. 211).

25. Stata User Guide Release 15. (2017). College Station, Texas: A Stata Press Publication.

26. Van Tendeloo, B., \& Vanstraelen, A. (2005). Earnings management under German GAAP versus IFRS. European Accounting Review, 14(1), 155-180.

27. Wu, G. S., Li, S., \& Lin, S. (2014). The effects of harmonization and convergence with IFRS on the timeliness of earnings reported under Chinese GAAP. Journal of Contemporary Accounting \& Economics, 10(2), 148-159.

28. Zéghal, D., Chtourou, S., \& Sellami, Y. M. (2011). An analysis of the effect of mandatory adoption of IAS/IFRS on earnings management. Journal of International Accounting, Auditing and Taxation, 20(2), 61-72. 